\title{
Lieutenant Colonel C T Samman, OStJ, MRCS, LSA, DPH Master of The Society of Apothecaries, 1928-31
}

\author{
Col (Retd) F G Neild \\ MFCM, MFOM
}

Member of the Court of Assistants of the Society of Apothecaries

Lieutenant Colonel Charles Thomas Samman RAMC retired from the service in 1920 and then began a second career as a barrister, having been admitted to the Middle Temple November 16, 1907, and called to the Bar January 26, 1910. In 1888 he had been made frec of the Society of Apothecaries, promoted to the Livery in 1891 and in 1921 was elected to the Court of Assistants. In 1926 he was elected to the Private Court and became Master in 1928. He was re-elected to this office in the two succeeding years and thus occupied the chair for a term which had not been equalled by a predecessor since Edmond Phillips, the founder Master of the Society in 1621.

Samman, the youngest son of Alban and Eleanor Marrion Samman, was born in Deddington, Oxon, on October 30, 1865. He was educated privately, trained at the London Hospital and qualified MRCS, LSA, in 1888. On January 30, 1893, he was commissioned Surgeon Lieutenant in the Army Medical Department and, after his initial training, was posted to Madras for his first overseas tour. On January 30, 1896, he was promoted Surgeon Captain and with the formation of the RAMC July 1, 1898, he became a Captain in the RAMC. In January 1901, he returned to Woolwich, took the DPH, London, and from February to November 1903, attended the Medical Staff College thus becoming one of the earliest Army preventive medicine specialists. In December 1903, he was posted to Jamaica, promoted Major on January 30, 1905, and returned to Eastern Command in March 1907. serving briefly at Dover and then Shorneliffe.

In January, 1911, he embarked on his second Indian tour and was posted to Mhow, Central India, where he described a case of eucalyptus poisoning 1 . In March, 1913, instead of taking his mid-tour leave entitlement via the three week journey home through the Suez Canal, he elected to travel "abnormal" passage via the Straits Settlements. China, Japan, Manila, Honolulu, the United States, Canada, the

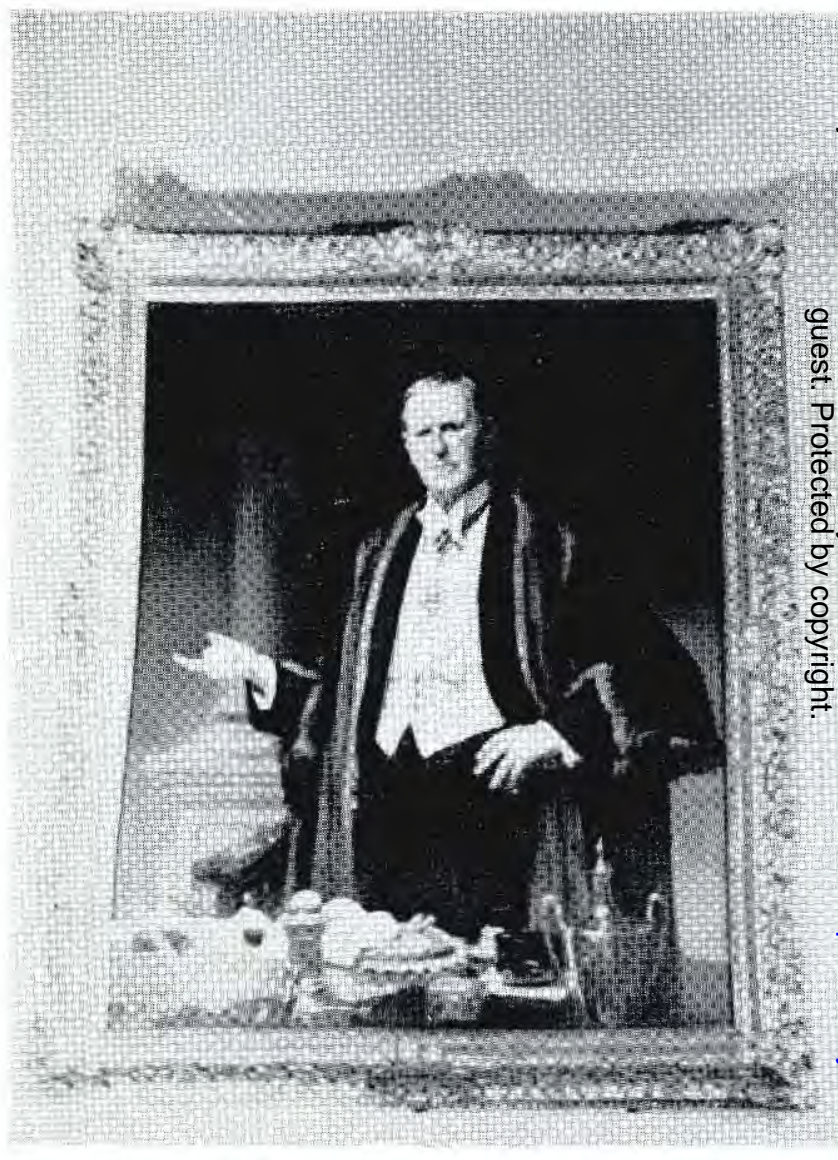

C T Samman, Master of the Society of Apothecaries

Panama Canal and the West Indies, a fascinati莡 journey of almost six months ${ }^{2}$.

Although his ticket home allowed him $350 \mathrm{lbs}$ ₹f baggage, shades of a more leisured society, the recommended his readers to travel light and restrs. themselves to one steamer trunk and two suitcases! In Rangoon he visited the Shwe Dagon Pago and watched the elephants stacking logs in McGres. 
gor's timber yard. While in Hong Kong he took the opportunity of going up by river steamer to Canton. In Japan he arrived in time to see the last of the celebrated Cherry Blossom Dances in Kyoto, saw the Imperial Palace in Tokyo and, of course the world famous Yosiwara to see how the Japanese regulate the "Social Evil." Later he saw the famous cormorant fishing at Gifu. He returned via Shanghai, where he transhipped for Manila. There he was shown around Bilibid jail recently built by the Americans and more like a school than a jail. In the latter, he was interested to see some of the prisoners doing bacteriological work in the laboratory. From San Francisco he drove to the Big Tree District of California and then visited Salt Lake City. In Chicago he visited the stock-yards where they could kill and dress 7,000 hogs and sheep and 2,000 head of cattle a day. He crossed Lake Ontario by steamboat to Toronto and then returned via Montreal and Albany and down the Hudson by riverboat to New York. He then sailed via Antilla, Cuba and Jamaica for Colon at the Atlantic entrance to the Panama Canal. The latter, to be opened the following year and still under construction, he was shown over in its entirety. He completed his journey via Carthagena and Puerto Columbia in South America and finally by Trinidad and Barbados to Cherbourg and Southampton.

On return to India he was promoted Lieutenant Colonel March 1, 1915, and then served in France with the 10th General Hospital and the 2/2nd London Field Ambulance the last few months of the war. He returned home that year and retired from the Army October 30, 1920. Having already been called to the Bar, he immediately started a second active career by becoming a Deputy Associate of the SE Circuit and was a familiar figure at the Chelmsford and other Assizes. He also practised at the North London Sessions and the Central Criminal Court.

In 1928 the Society was faced with the necessity of raising $£ 20,000$ to repair the ravages of the deathwatch beetle in the Hall, and the success of the appeal and of the subsequent restoration was largely due to Samman's energy and enthusiasm during his first term as Master. He was re-elected in 1929, when $\mathbf{H} \mathrm{J}$ Illott was unable to serve owing to ill-health and again in 1930 when Buchanan's duties at the Ministry of Health prevented him from? accepting the post. To commemorate these three years of office as Master, his full length portraie now hanging in the Parlour, was painted by $F$ ? Elwell ARA and presented to the Society by hi: friends and colleagues.

Samman was an Officer of the Order of St Johr $\stackrel{\mathbb{2}}{\Omega}$ of Jerusalem. He took a keen interest in locafs affairs at Ventnor, his home, and his favourite recreations were coaching and yachting. Because of later ill-health he and his wife wintered annually inw Simonstown, South Africa, and they had only re? cently returned home when he died May 17, 1939

Samman, an Edwardian figure, had a big framen and a marked personality. His interest was directeफ more to the dispensation of hospitality and charity and to the civic associations of the Society than tow the academic matters with which it had to deal a Medical Licensing Body. But he was always wi1 ing to support the proposals of his academic ced leagues. He expressed his opinions forcibly, sonat times more forcibly than was appreciated by the who differed from him. But he was always actuatôn by motives which appeared to him to be in the bêst interests of the Society.

In 1893 he married Eugenie, daughter of Janges Galloway, and they had a son and daughter. In 1931 he married secondly Louise Harriet Pfand Swinborne, younger daughter of the Rev $C$ : S Pfander DD and Emma Swinborne.

\section{REFERENCES}

1 Samman C T. Case of Eucalyptus Poisoning, $J R^{\nexists}$ Army Med Corps 1911; 17: 176-177.

2 Samman C T. A Trip Home from India, via Straits Settlements, China, Japan, Manila, Honolulu, UnitedB States, Canada, the Panama Canal and West Indies, ibid, 1914; 22: 334-346. 